\title{
Images of Childhood in Mothers' Accounts of Contemporary Childrearing
}

\section{Elizabeth Murphy}

Address for correspondence:

Professor Elizabeth Murphy

School of Sociology and Social Policy

University of Nottingham

Law and Social Sciences Building

University Park

NOTTINGHAM

NG7 2RD

UK

Telephone: +441159515403

Facsimile: +44 1159515232

Email: Elizabeth.Murphy@nottingham.ac.uk 
Images of Childhood in Mothers' Accounts of Contemporary Childrearing 
ABSTRACT

This article examines how a sample of first-time mothers in the UK constitute childhood in general, and their own children in particular, in and through their talk about the mundane practices of child-care. The data analysed are drawn from a longitudinal qualitative interview study which followed a sample of mothers from late pregnancy until their babies were two years old. The analysis explores links between mothers' representations of childhood and the actualities of their childrearing practices. The extent to which both the representations of childhood and the practices of individual mothers are consistent or contradictory, and change or remain constant over time, is also examined.

Keywords: childhood; images of childhood; child-rearing; childcare practices; infant feeding 


\section{Introduction}

This paper examines how mothers of young children constitute childhood in general, and their own children in particular, in their talk about child-rearing. I use the term 'constitute' to underscore the way in which understandings of childhood and children are social constructs, located in particular forms of discourse. As such, concepts of childhood and of the child are not neutral, objective, natural 'givens' but are impregnated with theoretical assumptions (Jenks 1996). They are 'knowledged into being' (Stainton Roger and Stainton Rogers 1992). Childhood is a social creation and, although 'truths' about childhood may appear to have the status of objective fact, in reality they reflect specific social and political preoccupations and concerns (Lawler 1999). In a very real sense, children and childhood are formed, 'made up' or constituted through these theory-impregnated forms of discourse which operate within both the specialist disciplinary worlds of, for example, paediatrics, psychology and sociology, and also in the common-sense world. These forms of discourse are discernable in the ways in which children are represented in everyday talk. As Ribbens (1994) argues, such representations draw upon 'typifications' (Schutz 1954), which are available in the socio-cultural world for individuals to draw upon to make sense of the behaviour of others.

There is a substantial body of, largely feminist, scholarship focussing upon dominant ideologies and social constructions of mothering and motherhood (see, for example, Bernard 1975, Hill Collins 1990, Apple 1995, Everingham 1994, Glenn 1994, Hays 1996, Lawler 2000, Miller 2005). However, motherhood as a social category is formed on the basis of the prior social category of childhood (Urwin 1985, Lawler 1999, Ribbens McCarthy et al. 2000, Miller 2005). As Lawler has argued, 'Motherhood is constituted on the basis of, and as response to "truths" about the nature of the child' (Lawler 1999: 65). Ideologies of 
motherhood are therefore predicated upon knowledges of childhood, and, in particular, of the needs of children. The assertion that something is a 'need' has a powerful impact upon the audience. It implies a factual basis and induces a sense of responsibility or guilt in those who fail to respond (Woodhead 1997). Within contemporary discourses around motherhood, children are formulated in terms of their neediness and mothers are positioned as the primary meeters of such needs (Everingham 1994). Indeed, the adequate meeting of children's needs is one of the defining features of good motherhood (Duncan and Edwards 1999). As a result, the needs of mothers are effaced, either by insisting that their needs are identical with the needs of their children or by denying that the mother's needs are needs in the true sense of the word (Lawler, 1999). Thus, children's needs are granted absolute priority and mother's needs claims are pathologised.

A recognition of the social construction of childhood is therefore of vital importance to discussions of motherhood. Nevertheless, as Lawler (1999) points out relatively little attention has been paid, in such discussions, to the social constitution of the categories of 'child' and of 'children's needs' (but see Alwin 1990 and Ribbens 1994). As a result, the ways in which knowledges about the child' contribute to the (largely non-coercive) subjection of mothers are overlooked. Data collected as part of a longitudinal qualitative interview study of mothers' choices about feeding their young children (Author 1999, 2000, 2003, $2004 a, 2004 b)$ offer an opportunity to explore the ways in which, in relation to this mundane area of child-rearing, mothers construct their children and call up 'knowledges' about children's needs. This paper examines how mothers represent children and childhood in their talk. It also considers how the representations (or motifs and images as Jenks (1996) terms them) were related to child-rearing practices, particularly in relation to infant feeding. The longitudinal nature of the data collected also allows us to examine how both 
mothers' constructions of childhood and their child-rearing practices change over time as their children move from babyhood to early childhood.

\section{Shifting Constructions of Childhood}

A number of authors have examined historical trends in the social construction of children and childhood (Aries 1962, Shorter 1976, Stone 1977, Pollock 1983, Cunningham 1991, 1995, Hendrick 1997). Using historical data, they have disrupted the assumption that childhood is a naturally-occurring, self-evident phenomenon which is always and everywhere the same. These authors have linked changes in the ways in which childhood has been represented to political and structural conditions. There is general consensus that constructions of childhood have undergone significant shifts between the Middle Ages and the present day.

On the basis of an overview of historical research on changing constructions of childhood carried out by such authors, Jenks (1996) identifies two dominant ways of talking and thinking about children: the Dionysian and the Apollonian. He argues that these are best seen as 'codes' or 'images arising from mythology' which may, at different times, be 'supported and reinforced by various religious beliefs, political ideologies and scientific doctrines' (p.70).

The Dionysian image of childhood is defined by an assumption that children enter the world with a bias towards evil rather than good. They are drawn to pleasure and self-gratification and lack self-control or sensitivity to the others' needs. This image is rooted in the Judaeo-Christian doctrine of original sin and rejects any notion that children are innocent beings (Stainton Rogers 2001). It was characteristic of seventeenth century Puritanism and subsequently re-invigorated during the Evangelical Revival of the late $18^{\text {th }}$ and early $19^{\text {th }}$ century with its 
emphasis on children as 'sinful polluted creatures' (Hendrick 1997: 40). Hannah More, founder of the Sunday School movement, warned against the 'fundamental error' of thinking of children as 'innocent beings'. Rather, she argued they are 'beings who bring into the world a corrupt nature and evil dispositions' (quoted in Robertson 1976: 421).

The model of child-rearing conventionally associated with this Dionysian image of the child is one of strict discipline and parental constraint (Stone 1977). Left to their own devices, children would turn out badly and, for their sake, parents must instil good habits from an early age. The metaphors associated with this parenting style are those of horticulture rather than natural growth: 'of preparing good soil, of rooting out weeds, of training young shoots in the direction you want them to go' (Cunningham 1995: 48). The emphasis is upon control, regulation and discipline (Stainton Rogers 2001). Jenks (1996) describes this approach to child rearing as 'one that saw socialisation as almost a battle but certainly a form of combat where the headstrong and stubborn subject had to be "broken", but all for their own good.' (p.71).

Jenks (1996) contrasts this Dionysian motif of childhood with the Apollonian which, he argues, is the preferred modern, Western, 'public' way of regarding the child:

Such infants are angelic, innocent and untainted by the world which they have recently entered. They have a natural goodness and a clarity of vision that we might 'idolize' or even 'worship' as the source of all that is best in human nature (73).

Cunningham (1995) places the emergence of this second image during the $18^{\text {th }}$ century. The implications for child-rearing were, in principle, profound. Apollonian children were to be encouraged to express their natural goodness. Rather than 
being shaped, controlled and constrained, as in the Dionysian model, they are to be nurtured, protected and enabled to develop their own innate potential. Adults were responsible for providing the environment for children's own natural goodness and individuality to flourish. 'The art of child-rearing became one of hearkening to nature, giving free rein to growth rather than bending twigs to a desired shape' (Cunningham1995: 62). Here the metaphor is of the prolific wild garden where seeds flourish naturally rather than of the strict horticultural regime required for the Dionysian child.

Conventionally these two images of childhood are presented in historical sequence, with the Dionysian preceding the Apollonian. However, while a significant move towards a more tolerant, child-centred approach is discernable from the $16^{\text {th }}$ to the $20^{\text {th }}$ century, Cunningham (1995) argues that motifs of childhood conventionally associated with pre-modern times, may, in fact, persist in contemporary understandings of childhood. Indeed, one might argue that the Dionysian image of the child, with its associated demand for parental control and constraint, is clearly discernible in recent UK policy developments such as parenting orders which may, for example, require parents to ensure that their children are at home at certain times or do not visit specified places.

Stainton Rogers (2001) suggests that these two motifs (or, as she prefers, discourses) of childhood co-exist and underpin diverse policy orientations towards children. Similarly, Jenks (1996) argues that although these two images are 'competitive to the point of incompatibility' (p.70), they nevertheless exist in parallel at the same time. There is, therefore, a danger of rendering constructions of childhood at particular periods appear more distinctive or patterned than they really were. The understandings of what it means to be a child, which are current in any given culture, at any particular historical period, 
may be more complex, contradictory and ambivalent than some historical accounts allow.

Other concerns have been expressed about the interpretation and implications of research on the construction of childhood. We are warned against perpetuating a triumphalist and/or presentist history of childhood, in which changes in understandings of the nature of childhood are interpreted as evidence of progress from unenlightened past to enlightened present (Jenks 1996; Steedman 1990). We are also reminded of the importance of examining empirically the relationship between images of childhood and concrete child-rearing practices (Pollock 1983). As Cunningham (1995) points out, these do not necessarily stand in a one-to-one relationship.

These considerations have been central to the analysis presented here. I examine the extent to which different understandings of childhood co-exist in mothers' talk and how they relate to practices in one central, highly contested but mundane aspect of contemporary child-rearing, that of infant feeding. I examine differences in how children are represented by mothers and how these differences relate to child-rearing practices. I also consider how both representations and practices change and develop over time.

\section{Material and Methods}

The data are from an interview study of the choices which first time mothers made in relation to feeding their babies and young children, which was funded by the UK Economic and Social Research Council. The overall aim of the study was to improve our understanding of the decisions mothers make in relation to feeding their babies and young children. From the outset the ways in which the mothers constructed their children and their needs, and the extent to which they presented their children as legitimate participants in decisions about feeding were 
central to the research. Issues around childrearing, particularly those of parental authority and control were identified, in advance, as important areas for investigation in the interviews.

The interviews were conducted in and around Nottingham, England. A cohort of first-time mothers was followed from late pregnancy until their babies' second birthdays. Following approval by the Local Research Ethics Committee and the General Practitioners' Local Medical Committee, access to six general medical practices, with diverse occupational class profiles, was negotiated. The general practitioners wrote to the women on their birth registers, inviting them to discuss participation in a study of whose aim was to 'improve our understanding of the choices which mothers make about what, when and how to feed their babies'. A leaflet explaining the study was enclosed and the researchers contacted the mothers who responded positively to this invitation to answer any queries and to negotiate formal consent.

To achieve heterogeneity, a quota sample of thirty-six mothers, stratified by age and occupational class (see Table One), was drawn sequentially from women who responded. Thirty-two women lived with a male partner, including two who lived with other members of his family. Three women lived with either one or both their parents and one lived alone. Twenty-three women were married. Two mothers, one each from the intermediate and lowest occupational class groups, were from minority ethnic groups (African Caribbean and South Asian). Fifteen had some post-compulsory education, and seven had attended college or university.

[TABLE ONE ABOUT HERE]

Six qualitative interviews were conducted with each woman in her own home, one before the birth and five at fixed intervals over the subsequent two years. The 
interviews were conducted by one of two researchers. The analysis presented here is drawn from the interviews at two months and two years. Interviews lasted between one and two hours. Interviews with thirty-three women were tape-recorded and fully transcribed. Detailed notes were taken of interviews with three women and fully written up immediately afterwards. The interview transcripts were anonymised by substituting pseudonyms, for the names of mother, baby, partner, health professionals, and any others named in the course of the interviews. Transcripts were reviewed for any other identifying material and this was removed.

A sub-sample of twelve women, reflecting variations in age, occupational class and feeding practices, but not in ethnicity, was selected for preliminary analysis. Transcripts for this sub-sample were subjected to inductive analysis by the author and two research associates. Each investigator examined four transcripts in detail and produced written reports identifying emerging themes and categories. The emerging analysis was discussed in weekly meetings, related to relevant literatures, and developed into a coding framework, specifying operational definitions for each code. This framework was applied to the remaining interviews. Difficulties were discussed and the coding handbook amended before the revised coding was applied to the full data set. Although the analysis was primarily inductive, it involved the interplay between research questions identified in advance, 'foreshadowed themes' (Glaser and Strauss 1967), previous theoretical and empirical work and the data, which is characteristic of much qualitative research (Emerson 1983, Murphy and Dingwall 2003).

At the end of the study period, a printed summary of the project's results was sent to the participants who were invited to contact us with any comments or feedback. We considered but rejected the possibility of holding a face-to-face briefing for the study participants on the grounds that this might compromise 
their anonymity. While a number of the participants did subsequently contact members of the team, no substantive comments about the research findings were received.

\section{Results}

Newborn babies

The child's state as he or she enters the world is central to both images of childhood discussed above. The Dionysian child is born with a bias towards evil. From birth, the Apollonian child is endowed with essential goodness. In this section, I explore the extent to which mothers' representations of childhood reflected one or both of these images and consider the implications for childrearing practices. Data are from the interviews conducted two months after the births.

At this early stage, nearly all mothers embraced the Apollonian motif of the innocent, self-regulating child. Babies could be trusted to identify their needs and not to make inappropriate demands. Many mothers described their babies as demanding and even coercive but treated their demands as entirely legitimate. Mothers sought to meet rather than resist their babies' demands. For example, one mother said,

I just go along with him really. I've not tried that much to make him go this or that ... if I think that milk is all he wants then I feed him (Alison, Older, Intermediate, $\left.\mathrm{WB}^{\mathrm{i}}\right)$.

The behaviour of these babies was not presented as wilful or deviant, as demonstrated in excerpts from interviews with Tracey and Rosemary,

I mean really I was rooted to the sofa and she was wanting to feed all the time which I hadn't prepared for ... I felt like I was stuck and in order that I ate I needed other people here to feed me. They were doing things like 
making me food and literally bringing it in and giving it to me so that I could carry on feeding her. ... I would suddenly find that you know for two hours she was wanting to feed almost continuously in the afternoon. (Rosemary, Younger, Highest, WB)

I was actually letting her feed every time she wanted but I spent almost the whole evening feeding her like I say from about 6 until 12 with only sort of the odd hour off and so I mean ... that's quite difficult but I accept that's what she wants if that happens. (Tracey, Older, Highest, WB) The use of the word 'want' in these two excerpts is interesting. In relation to older children and adults there is a sharp conceptual distinction between needs and wants. As discussed above, the identification of needs carries with it a strong moral obligation to meet those needs (Woodhead 1997, Lawler 1999). Needs are defined as unconditionally legitimate. Wants, on the other hand, are only conditionally legitimate, particularly when their satisfaction depends upon another's co-operation. They call for a judgement about reasonableness. There is no such distinction in this talk about very young babies. Here 'need' and 'want' are used interchangeably. To fail to meet either is described as 'cruel', as in the following excerpt,

I didn't see any point that if she was, if after only two hours after a feed, if she lay crying, screaming and whatever else, I thought it would be cruel to leave her. ... I don't agree with leaving her to cry if she is hungry (Helen, Younger, Lowest, WB).

This conflation of needs and wants in such talk reflects a widespread understanding of small babies as self-regulating and the strong message from many contemporary child-rearing manuals that it is impossible to spoil a baby in the first year of life. For example, babies were trusted to know how frequently they needed to be fed, 
'I fed her when she wanted it. ... You can't sort of feed her when you're ready. You've got to feed when she's ready.' (Daphne, Older, Intermediate, WB)

Babies' demands may not be consistent from feed to feed or day to day but they can be trusted to balance out their requirements,

She tends actually to have a six ounce the next feed and then the feed after she'll want a bit more and then she'll have eight ounces again and then she'll go to six and she lets me know she's still hungry. She'll scream when you take the bottle away or if she's finished it. So I have to rush out and get her some more ... if she started taking more all the time then I'll make a bigger bottle. (Annette, Older, Lowest, WB).

The image of the child embedded in these descriptions is Apollonian. These babies are understood to be innocent, spontaneous and self-regulating. They are trusted to identify their needs and the mother's task is to interpret and respond. There is no suggestion here that the baby might be wilful, manipulative, selfindulgent or greedy. The implications for mothers are profound. As Lawler (1999) argues, mothers' own needs are effaced as they are positioned as primary meeters of their children's unconditionally legitimate demands.

These mothers rejected advice that failed to honour the babies' innocence or attempted to override the babies' self-regulation. Sometimes health professionals were criticised for failing to recognise the babies' self-regulating capacity. For example, Julia challenges the notion that her baby's unwillingness to feed was 'naughty',

One or two of the midwives were saying, 'Oh you naughty baby, blah, blah, blah and I thought, 'Well, how can she be naughty?' you know. That was sort of as if it was her fault (Julia, Older, Highest, WB). 
Such 'naughtiness' would imply wilfulness, a suggestion that Julia derides. Mothers frequently described battles to protect their babies from officious interference, particularly from health professionals. For example, Diane described a midwife persuading her to make her baby feed:

There was a very young midwife on that night and she said, 'You really must try harder than that Mrs X. ... He'll be awake all night if you don't feed him more than that'. I said, 'Well he obviously doesn't want to feed, otherwise he would feed'. 'Try again', she said and she tried to latch him on. I mean obviously he didn't want to and she just bustled away (Diane, Older, Highest, WB)

This mother reasserts her confidence in her baby's capacity for self-regulation. Similarly, Helen, rejected her health visitor's suggestion that she should limit her baby's intake of food:

My old health visitor ... used to say to me, 'Well, you know you really shouldn't be giving her that much. She doesn't need it' and whatever else and I turned round and said, 'Well, I think she does. She takes it, she needs it, she knows when she's had enough' (Helen, Younger, Lowest, WB)

Here Helen confronted the suggestion that she was confusing wants with needs. The health visitor categorised the baby's consumption as illegitimate because it was more than babies 'need'. The mother rejects this advice and reaffirms her baby's self-regulating capacity.

These women insist that their babies should be protected from officious interventions from whatever source. Barbara and Rosemary described their commitment to being baby-led:

Going by how I feel personally I think you go by what, how the baby feels ... It's not how we feel, it's how the baby feels.' (Barbara, Older, Intermediate, WB). 
That's my aim really is not to do that (control the baby) and not to be sort of imposing because I don't know. I really don't know you know (Rosemary, Younger, Highest, WB).

Several mothers told salutary tales about being tempted to doubt their babies' capacity for self-regulation and/or innocence. Such stories always ended with the mother showing how such doubts had proved baseless and a reassertion of the babies' trustworthiness. Bryony described frustration with her baby's apparent stubborn lack of co-operation:

I tried to latch her on and she took and I thought, 'Oh great you know, wonderful' but within like thirty seconds she'd dropped off, was crying she wanted a feed and I thought, 'Well, it's there, what's the matter with you. You know and I was like not losing my temper with her but I was getting so frustrated because I thought, 'Well, what do you want, woman? It's there, come on, take it. Why are you dropping off, you know? You're hungry, there's milk there, why are you dropping off? (Bryony, Younger, Lowest, WB)

Up to this point, the mother's frustration appears justified. The baby's demand for food, followed by refusal to take it appears wilful. However, faith in the baby's innocence is restored as we discover that the mother had developed an undiagnosed breast infection making feeding difficult,

I think what it was, me boob had swelled up that much ... it was that hard she couldn't suck the nipple out enough so she just weren't interested.

Other mothers told similar stories of initial doubt followed by restoration of faith. They described how they had been tempted to impose structure but had since concluded that this was inappropriate. Christine commented upon her attempt to stretch the time between feeds: 
I tried to make him wait at least three hours ... but he was just crying all the time and being miserable, so I thought, 'Why should I make him be miserable?' If he's hungry I feed him. He's only a baby; that's how I see it. (Christine, Younger, Highest, WB).

Like Christine, many of the women linked their commitment to being baby-led in their feeding practices to the special status of their children as 'only babies'.

Thus, most mothers drew on Apollonian motifs of innocence, trustworthiness and self-regulation. Any suggestion that their babies' behaviour was deviant and therefore sanctionable was dismissed. There were, however, three women whose talk constituted their babies in very different ways, reproducing elements of the Dionysian motif. They presented their babies not only as difficult and demanding but also as naughty, manipulative, out of control, impatient and uncooperative.

For example, one mother clearly interpreted her baby's behaviour as wilful:

She'll spit it (dummy) out on purpose because she knows I'm gonna damn well stick it back in ... sometimes she just, she has this thing. ... I'll put the dummy in and she'll look at me and go 'plop' and spit it out and I'll ignore her and she'll try and get it back in, going like this [gestures with hands]. So I, because to me that's obvious she wants it, so I'll put it in and then, blow me, she spits it out again and I'll say, 'No, Joanne, I'm not doing it again' and I ignore her and she'll sob, sob, sob, trying to get it and I say, 'Why are you doing this?' and it drives me up the wall'. (Dilys, Older, Intermediate, AC)

This mother undermines any suggestion that this behaviour is accidental or inevitable. Spitting the dummy out is not interpreted as expressing need. The baby's intentionality is emphasised. She is described as spitting the dummy out 'on purpose'. The reference to looking at her mother before she spits the dummy out implies defiance and manipulativeness consistent with the Dionysian motif. 
Sally also categorised her baby's demands as illegitimate,

She's got a real temper on her when she's hungry. She just screams you know and won't calm down and I found when I was trying to breast feed her she wouldn't hold her mouth still for me to, to latch her on. ... She just wouldn't calm down and wait for two minutes even though she had been asleep one minute earlier, you know, she was really, 'I want it now in my mouth. I don't want to wait' (Sally, Younger, Highest, WB).

This baby is presented as wilfully refusing to co-operate with attempts to feed her. Her impatience and bad temper are portrayed as unjustified given her mother's efforts. Sally, who was a part-time undergraduate student, went on to allege that her baby's demanding behaviour was a deliberate attempt to sabotage her other activities,

I mean, just the other day she was really grumpy all day and I think it was because she knew I had to get my college essay done, you know. Like Sally, a third mother, Beatrice, represents her baby as wilfully uncooperative, A terrible lot of pressure was put on me to breast feed and it just wouldn't work. I mean there was plenty there for her but she just wouldn't have it and what can you do? ... You can't force a baby to breast feed. It's just impossible ... she wouldn't have it and what do you do? (Beatrice, Younger, Intermediate, WB)

In presenting their babies as wilful and manipulative, these women cited health professionals' opinions, as in the following excerpts,

Well she's obviously a very naughty little girl and she doesn't want it you know, give her a bottle (Beatrice, Younger, Intermediate, WB). 
This last week and a half, the health visitor said, 'Oh, she's wrapping us round her little finger and every time she's crying a lot she's associating that with more milk' (Sally, Younger, Highest, WB).

These three mothers' talk reproduces many elements of the Dionysian motif. The babies are seen as having a bias towards wilful, manipulative and self-destructive behaviour.

The marked contrast between the two groups of mothers discussed above reinforces the importance of recognising the heterogeneity of understandings of childhood prevalent at particular periods (Cunningham 1995; Jenks 1996). While most mothers in our sample reproduced versions of the Apollonian child which is argued to be the predominant motif in contemporary Western societies, just three characterised their children in ways closer to the Dionysian motif. Of these three, one (Dilys) was the only African Caribbean woman in the sample. However, as the sample was not designed to explore differences between mothers from different ethic groups, it is not possible to speculate about whether this Dionysian image of childhood is more or less prevalent among African Caribbean mothers.

How, then, do these two different constructions of childhood relate to childrearing practices? For mothers who rejected the notion that newborn babies are capable of making illegitimate demands, the implications practice appeared straightforward. If babies' demands are, by definition, this removes any imperative to 'break the will' of a potentially anarchic baby. These mothers emphasised the importance of meeting babies' demands as fully and immediately as possible. As Christine put it,

I just go along with what he wants. I just go along with him really. (Christine, Younger, Highest, WB) 
This reflects the tolerant, sympathetic, child-centred approach conventionally associated with the Apollonian motif.

For the three mothers, who constituted their babies as fully fledged agents, capable of wilful manipulation and acts that are damaging to themselves and to others, the implications for child-rearing practices were less straightforward. These mothers presented themselves as impotent in the face of their babies' wilfulness. The babies were portrayed as having the upper hand. This is evident in some of the excerpts reproduced above where, faced by their babies' intransigence, the mothers made comments such as,

It's just impossible ... she wouldn't have it and what do you do? (Beatrice, Younger, Intermediate, WB)

Thus, although these women's constructions of their babies are consistent with the Dionysian motif, this was not linked to the repressive child-rearing practices which conventionally associated with it. Although frustrated and even incensed by their babies' behaviours, the mothers reported appeasing rather than resisting their babies' demands. As Cunningham (1995) has argued, ideas about childhood do not necessarily stand in a one-to-one relationship with the actualities of childrearing.

In summary, most, but not all, mothers of newborn babies constituted their babies in ways that reflected the Apollonian motif of the trustworthy, selfregulating, innocent child and eschewed repressive, controlling or disciplining approaches to child-rearing. This reflects Murcott's finding (Murcott 1993) that adult rules are suspended for babies 'on the grounds that they can do no other'. Murcott contrasts the social accommodation of babies with the treatment of adults whose capacity for bodily self-management is also compromised: the very old, the incontinent, the sick and the insane. She points out that, while these groups may be absolved insofar as their deviant behaviour is deemed 
unmotivated and involuntary they nonetheless risk constantly the ascription of spoiled identity (Goffman 1963) in a way that babies do not. Murcott suggests that the differences between social response to babies and to other groups who share some of the incapacities of babyhood relate to the reversibility of babies' inability to follow the rules. While this is no doubt true, the data presented here suggest that another factor is also in play. For these mothers, the imperative to accommodate their babies' demands was grounded in the conviction that these demands reflected genuine needs on their babies' part. Unlike, for example, the very old or the insane, whose judgement is frequently called into question, these babies were trusted to self-regulate.

I now consider whether and how this view of babies as innocent, trustworthy and self-regulating had attenuated by the time their babies had reached their second birthdays.

Two-year olds

Two years after the births, major shifts are observable in the mothers' descriptions of their children. Children were now presented routinely as knowing and manipulative. Terms like 'naughty', 'mischievous', 'on purpose' and 'playing up' are now common. One woman described her child's exploitation of her grandparents,

They're making a rod for their own back really because I wouldn't appreciate it. I mean I wouldn't like it if Jane was coming home and the first thing she said is 'Choc, choc' because I would feel like she's using me for what she can get and I feel that is what she does with my Mum and Dad. She's actually using them for what she can get, because children are like that. (Bryony, Younger, Lowest, WB). 
Bryony suggests Jane has demonstrated a calculating, instrumental attitude to grandparents' generosity. Their relationship is grounded in self-interest rather than the reciprocity of a loving child-adult relationship. The comment that, 'children are like that' indicates that Bryony sees such instrumentality as characteristic of all children. Here one can see hints of the Dionysian motif emerging.

By the age of two, all the children were presented as capable of wilful misbehaviour. Their intentionality was stressed. For example, Helen described her child's behaviour at mealtimes:

When she does throw her food about I think she's doing it on purpose rather than having accidents. (Helen, Younger, Lowest, WB)

The mothers emphasised their children's capacity for knowing right from wrong. Elaine remarked,

He's a very active child but very switched on as well. Sort of quite naughty sometimes, even though he knows not to do something he'll do it (Elaine, Older, Highest, SA)

This idea that children are choosing to misbehave was central to many mothers' talk about their children. Carol talked about her child refusing food, behaviour which she designates 'naughty'.

She knows it's naughty ... she'll push things away and she'll say, 'Grace naughty girl, Grace naughty' and she'll say, when we've eaten ours, 'Daddy's gone, Daddy's good, Mummy's gone, Mummy's good, Grace's not gone, Grace naughty. So she knows. She really knows everything about it. (Carol, Younger, Intermediate, WB)

Children were presented as wilfully manipulating their parents, as illustrated by the following two excerpts,

She'll think, 'Oh I can get away with this' and she will, she won't have her Weetabix ... he'll [child's father] say, 'Come on then Ruth, you're gonna 
have your breakfast,' she'll wind him up, ... and she's laughing, thinking, 'Oh I've won this round. ... I haven't got to have Weetabix after all'. (Dilys, Older, Intermediate, AC)

He uses drink as a delaying tactic at bed now. I think he's cottoned on that we try to get him to drink all the time and ... he has his milk with him into bed. He'll say, Anthony want milk', so I'll have the milk there and I'll give it to him and, 'No, Anthony want tea', so I bring the tea up and he has a sip, 'No Anthony want fizzy' (Rita, Younger, Highest, WB).

Such intentionality is presented as an emergent quality, linked to the child's growing maturity. For example, Alison comments that,

He does know now and he's old enough to know that you know he should sit and eat his meal ... so he knows exactly what is going on. (Alison, Older, Intermediate, WB)

Here there is an implicit contrast between what he knows 'now' and his earlier more limited capacity to understand the 'rules' of appropriate behaviour. Elaine (Older, Highest, SA) describes her child as 'slowly learning to play the system.' Bryony suggests that her child's attempts to manipulate potty training indicate a stage she had reached:

But then you see she'd got to the stage where she'd go and wee and then want a sweet and then she'd go back two minutes later and do a little dribble again you know but it got to where she'd come and she'd say 'I weed, sweeties' you know. I was like, 'oh no, you don't get sweeties, you don't wee just to get a sweetie'. (Bryony, Younger, Lowest, WB) Thus, contrary to some formulations of the Dionysian motif, wilfulness and naughtiness are not seen as inborn characteristics. Rather they are a developmental stage attained as the children become intentional actors. 
As noted above, most mothers of newborn babies collapsed any distinction between needs and desires. This, too, had changed radically by the time the children were two. A clear distinction emerged between demands and needs. This was evident in the mothers' concern that their children might demand unhealthy food or refuse food needed to maintain health. For example, Christine expressed concern that, if not restrained, her child would become obese.

I've asked her [childminder] ... just to give him juice and to cut down on his milk now. ... He's portly ... I mean he would drink all day. He would if you let him I'm sure. ... I am in control of what he eats so I've got to look out for him haven't I? (Christine, Younger, Highest, WB)

The sense that children could be seen unequivocally as self-regulating had disappeared from the mothers' talk. This is not to say that individual children were never trusted to make good choices. For example, Dilys described how her child moderated her intake of sweet food,

She tends to, she tends to just moderate her intake anyway. She seems to regulate it. She won't go barmy for jelly and ice cream. She'll have a bit of it, she'll have a taste. (Dilys, Older, Intermediate, AC) However, such trust in the child's ability to self-regulate was no longer unconditional. It had to be earned. It was based on observation of particular aspects of the child's behaviour. Simply because children self-regulated in one area, this did not mean that they could be trusted in other areas. This is illustrated by a further excerpt from Dilys's interview,

My husband drinks bitter and lager and I like wine and I dread to think what we're gonna do with her. I just, because she insists on having a sip and you can't say, 'Oh here, have a sip and then that pacifies her. It doesn't, she just wants more and more. .... I have some real tantrums when I won't let her have any more' (Dilys, Older, Intermediate, AC) 
Thus, although Dilys's child is trusted to moderate her demands for sweet foods, her demands for alcohol are seen as uncontrolled.

By two years, the mothers routinely talked about their children in ways that drew less upon the Apollonian and more upon the Dionysian motif of childhood. While they avoided the somewhat archaic language of 'evil' they nevertheless portrayed children as drawn to pleasure and self-gratification and lacking self-control or sensitivity to the needs of others (James, Jenks et al 1998). The children were all presented as intentional actors whose demands were potentially illegitimate.

As we have already observed, there is no necessary correspondence between the ideas that people hold about childhood and the actualities of child-rearing practice. I now turn to consider to what extent the major shifts in constructions of childhood between two months and two years were reflected in descriptions of child-rearing practice.

Conventional accounts of the Dionysian motif associate this image of childhood with repressive and controlling childrearing practices intended to socialise, shape and even 'break the will' of the child. There were, indeed, indications of such approaches in the talk of some women. For example, Belinda described how she enforced the requirement that her child should eat up at meal-times,

It's a case of 'if you don't eat your lunch you're not having a load of crisps and things' because you know I tend to think well, she'll have to eat her tea (Belinda, Older, Lowest, WB).

Some mothers also described how they seek to discipline disobedient children, If the mood takes him, sometimes he's terrible and he won't eat his dinner and he just runs off and I don't give him anything to eat then. If he's naughty I take his meal off him and he doesn't get anything. ... He's had nothing some days from early in the afternoon. He's refused or played 
with his dinner and I've taken it off him and then he's had nothing until the next day, drinks obviously, ... I'm not bothered if he misses a few meals but I'm not, I don't want him to be naughty at meal times. If he messes with it, that's it. (Christine, Younger, Highest, WB)

There is also some talk which focuses on avoiding or redressing bad habits. Sally described how she used physical chastisement, She doesn't do it any more but she started to have a little habit of when she'd had enough breakfast cereal, to bring the rest of the milk on to her tray and whiz her hand around in it but we've just about got rid of that now because if she does it she gets a smack, so. (Sally, Younger, Highest, WB)

However, the child-rearing practices described by the women were far from homogeneous. Although drawing on Dionysian motifs, many of the women distanced themselves from more controlling or directive approaches to childrearing. Their practices were much closer to the laissez-faire approach associated with the Apollonian motif. For example, Hilda described her approach to her child's diet,

He gets what he wants ... he gets his own way all the time. I mean it doesn't really bother me. ... I don't see it as a problem. I just let him get on with it and I mean, as he gets older, he'll probably eat more, at regular times like when he gets to nursery and then school so I just leave it up to him ... Kids are kids. All kids are different. They'll eat what they wanna eat and drink what they wanna drink. (Hilda, Younger, Intermediate, WB).

These mothers emphasise the self-determination they accord to their children, If she doesn't want it, I don't try to force it down (Angela, Younger, Intermediate, WB) 
They give a variety of reasons for accommodating their children's wishes. In some cases, they suggest that while, in principle, they would like to exert more control, they are powerless to do so.

In an ideal world I'd like her to sit down, real quiet, sit still, eat her dinner with a knife and fork or a knife and a spoon whatever and have no problems but it doesn't work out that way does it? (Helen, Younger, Lowest, WB)

Dilys described her anxiety about her child's food intake, her attempts to control it, and her ultimate acceptance of the conditions under which her child was willing to eat,

It worries me if she puts her foot down and won't have Weetabix because ... she went through a phase, the health visitor called it hamster syndrome ... rather than just not having any more food in they keep it in their mouth and puff their cheeks up so you can't get any more in ... It got me really annoyed and I was push, push, push like this to her cheeks. ... I was going swallow, swallow but she wouldn't ... my dad would have called it bloody naughty, he wouldn't have said it was hamster syndrome. ... I know she's dictating to me but if it's, if she's gonna be happy and it means eating all her dinner then she can sit within a foot of the television. (Dilys, Older, Intermediate, AC)

In some cases, the mothers judged that the effort required to enforce control over the children was disproportionate,

He's mad for coffee. I try not to give him too much but it's a bit hard because he demands it and if he don't get it he has a tantrum. (Hilda, Younger, Lowest, WB)

Some mothers described how, earlier more directive approaches had been revised in the light of experience. For example, Harriet described her changed practice, 
It can be very stressful you know ... actually face to face you know, your sort of stress levels rise very, very rapidly I've felt when I was battling with her ... I try not to let myself now because ... if I start to feel that way and you know she's obviously getting wound up I just drop it and just get out of the situation you know, just take her out of her high chair and just forget whatever I was trying to do with her you know and just sort of resign myself to the fact that you know. (Harriet, Older, Highest, WB) There is no suggestion here that the judgement of the child's behaviour as inappropriate has changed. A more permissive approach to child-rearing has been adopted because the stress to both mother and child were judged excessive. Similarly, Harmony described how she had stopped 'forcing' her child to eat, What she doesn't eat then I chuck away. I used to force feed her but I don't do that now. I don't, what she don't eat I chuck away. (Harmony, Younger, Intermediate, WB)

A number of mothers attributed their reluctance to adopt a more directive style of parenting to concerns about their children's physical or psychological welfare. Carol described how she had oscillated between more controlling and more permissive practices in relation to her daughter's food intake, I'm finding it very difficult with her ... I've tried to say ... 'Right, she eats what we have, if she doesn't eat it that's fine, but she's not having something different' but then I just panic and worry because her food intake for that day has been next to nothing. (Carol, Younger, Intermediate, WB)

Sarah described how her concern to ensure that her child drinks enough fluids forced her to accept his preference for coke.

He's a big coke fan as well ... It'll be like, 'No, have some juice', 'No, coke' and you're like, 'Oh, so' but then you're back to that Catch 22. I'd rather him drink something than not at all. (Sarah, Younger, Intermediate, WB) 
Helen expressed anxiety that an overly directive approach to parenting might be counter-productive,

We try all sorts, coaxing her, bribing her, forcing her but she's so strongwilled that you've got to walk gently else you'll push her further away. (Helen, Younger, Lowest, WB)

Dilys described her concern that her child might develop a 'complex' if forced to eat something she did not want,

If she puts her foot down and won't have her cereal and you know, I'll go, 'Right', but I won't force it into her because I don't want to give her a complex about it. (Dilys, Older, Intermediate, AC)

This concern about potential psychological damage and future consequences of over-riding her child's food preferences is also evident in Harriet's talk,

I was actually having to sort of physically force it into her mouth and you know it was really upsetting me and upsetting her and you know we were going nowhere so I just, in the end, just decided right, well, ok, we're gonna feed you what I know you will eat and you know since then it's been a lot better ... mealtimes are not a battleground now and I do worry about things like that you know because I, oh you know, what are we doing to them, what are they gonna be like in years to come, are they having problems with you know food, er, eating disorders and things, so I didn't really want to start getting into you know a crisis situation with her. (Harriet, Older, Highest, WB)

Thus, many of these mothers combined a construction of their child which approximates to the Dionysian motif, with a reluctance to adopt the controlling, directive, even punitive styles of child-rearing that have been associated with that image of childhood. This reluctance was grounded in concerns about physical or psychological damage and impotence in the face of children's recalcitrance. 


\section{Discussion}

I have examined contemporary mothers' constructions of babies and young children and the ways in which such constructions relate to one area of childrearing practice. Focussing on talk about infant feeding has enabled us to look at the concrete reality of the mother's practices in one specific area of child-rearing and the ways in which these do or do not articulate with their understandings of what it is to be a child. Feeding is one of the 'nitty-gritty issues of daily life' (Ribbens 1994: 145) where underlying cultural assumptions about the nature of childhood are likely to be played out. It is not the only such issue and, indeed, other issues including sleep and cleanliness might raise different issues for the mothers. Nevertheless, in studying infant feeding, it has been possible to examine apparent contradictions between the ways in which some mothers construct their young children and the childrearing practices they feel comfortable in adopting.

The contrasting representations of childhood identified by other authors are evident in these data. Apollonian themes of natural goodness and innocence are observable, particularly in the early interviews where most mothers present their babies' demands as characterised by necessity and, therefore, as unconditionally legitimate. Similarly, stripped of the archaic language of original sin and demonic forces, the mothers' talk in later interviews reproduces elements of the Dionysian motif identified by Jenks (1996). While the mothers might hesitate to use the term 'evil' about their children, they do, at two years, present them in ways which fit Jenks's definition of the Dionysian motif: '[the child] loves pleasure, it celebrates self-gratification and it is wholly demanding in relation to any object, or indeed subject, that prevents its satiation.' (Jenks 1996:71)

As we have seen, while most mothers construct their newborn babies in Apollonian terms, the talk of just three mothers is closer to the Dionysian motif. 
The difference between these two groups of mothers does not lie in the objective behaviours displayed by their babies. Both groups of mothers described their babies as demanding and even coercive. The difference is in the ways in which the mothers interpret such behaviours. As sociologists of deviance have long argued, the designation of an action as deviant or otherwise does not depend upon the outcome of that action. Rather, like childhood, deviance is socially constructed and depends upon the interpretation of the action in question (McHugh, 1970). It is only where an action is deemed both avoidable and intentional that it is likely to be treated as illegitimate. By definition, needs are unavoidable. Where mothers interpret their babies' demands as the reflection of genuine need and reject the possibility that their babies might be acting manipulatively, they are unlikely to treat such demands as illegitimate.

These data reaffirm the importance of recognising the complexity and ambivalence of the images of childhood which are current within particular cultures at particular periods. Different constructions of childhood co-exist (Jenks 1996). This is demonstrated, in particular, by the data presented in relation to newborn babies. Although most mothers presented their babies as innocent, selfregulating and trustworthy, in keeping with the Apollonian motif, three women constructed their children very differently. These babies were seen in ways which more closely drew on Dionysian ideas of children as 'wilful material energy' (James, Jenks et al. 1998: 10). While no clear differences were identified between women of different occupational or ethnic groups, this may attributable to the small sample and should not, therefore, be taken as evidence that no differences exist. In particular, the very small numbers of women from ethic minority groups could be masking cultural diversity in both constructions of childhood and approaches to child-rearing. This is an issue which could usefully be examined in future research. 
These women do not, of course, construct childhood ex nihil. Rather, as Schutz (1954) suggests, commonsense talk, of the kind analysed here, draws upon the typifications of childhood which are available in their socio-cultural worlds. The 'truths' about childhood which are reflected in such typifications are strongly influenced by specialist discourses, particularly within medicine and the 'psy' professions (Rose 1996, Lawler 1999). The health care professions, child-care publications and familial and neighbourhood networks all act as conduits through which these specialist discourses are transmitted and come to form part of common-sense ideas about childhood, child-rearing and the responsibilities of motherhood (Miller 2005). However, as we have seen, women are capable of resistance also. Some of the women were, for example, very dismissive of midwives and health visitors' attempts to challenge mothers' representations of their newborn babies as innocent and self-regulating. Mothers cannot, therefore, be understood simply as 'cultural dopes who unselfconsciously mimic' the ideas and child-rearing methods of others (Hays 1996 p.75).

Historical analyses of images of childhood have emphasised the centrality of the child's state at birth. Thus the Apollonian child is born with a bias towards good and the Dionysian with a bias towards evil. The analysis presented here questions such continuity between the constructions of babyhood and of later childhood displayed by contemporary UK mothers. These mothers distinguish between their newborn babies' trustworthiness, innocence and self-regulation and their later bias towards self-gratification, insensitivity and lack of self-control. The only exceptions to this are those three mothers who drew on Dionysian motifs when their babies were newborn and carried these forward into the later interviews. For most mothers, the move from Apollonian innocence to Dionysian self-indulgence is seen as a developmental stage. 
These data also underline the disjunction between images of childhood at particular historical periods and the child-rearing practices which may or may not be linked to them. It is clear that the relationship between images of childhood and child-rearing practices is asymmetrical. Where mothers drew on Apollonian images, the implications for child-rearing were relatively straightforward. Mothers are to interpret and meet their babies' expressions of need. Where Dionysian images predominate and babies and children are constituted as intentional agents whose demands may go beyond their legitimate needs, the links between image and practice are attenuated. Some mothers do report childrearing practices which approximate to the model of 'strict discipline and parental constraint' (Stone 1977) which has been linked to this image of childhood. However, many reject this view of socialisation as a 'battle' (Jenks 1996: 71) either because they view it as unenforceable or because they fear the short and long-term consequences of attempting to apply it.

This paper has examined the images of childhood drawn upon by a group of UK mothers of babies and very young children and the ways in which these relate to mundane practices of child-rearing. In doing so, it has substantiated many concerns about interpretations of historical trends in images of childhood which treat these are more homogeneous, more consistent and more unequivocally linked to child-rearing practices than they necessarily are. It also suggests that constructions of childhood are emergent and linked to stage of development which children are deemed to have reached at particular ages. This suggests that it would be worthwhile to extend the analyses presented here by examining the images and practices associated with older children in the UK and with both younger and older children in other countries. 


\section{References}

Alwin, D. (1990) 'Historical changes in parental orientations to children,' in P. Adler (ed) Sociological Studies of Child Development, vol. 3, pp. 65-86. Greenwich, Connecticut: JAI Press Inc.

Apple, R. D. (1995) 'Constructing mothers; scientific motherhood in the nineteenth and twentieth centuries,' Social History of Medicine 8 (2): 161-178. Aries, P. (1962) Centuries of Childhood: A Social History of Family Life. New York: Vintage Books.

Bernard, J. (1975) The Future of Parenthood: the New Role of Mothers. London: Calder \& Boyers.

Cunningham, H. (1991) The Children of the Poor: Representations of Childhood since the Seventeenth Century. Oxford: Blackwell.

Cunningham, H. (1995) Children and Childhood in Western Society since 1500 Harlow: Longman.

Duncan,S. \& Edwards, R. (1999) Lone Mothers, Paid Work and Gendered Moral Rationalities. London: Macmillan

Emerson, R.M. (1983) Contemporary Field Research: A Collection of Readings. $1^{\text {st }}$ edition. Prospect Heights Ill.: Waveland.

Everingham C. (1994) Motherhood and Modernity. Buckingham: Open University Press.

Glaser B.G. \& Strauss, A.L. (1967) The Discovery of Grounded Theory: Strategies for Qualitative Research. Chicago: Aldine.

Glenn, E.N. (1994) 'Social Constructions of Mothering: a Thematic Overview.' In E.N. Glenn, G. Chang \& L.R. Forcey (eds) Mothering, pp.1-29. New York: Routledge.

Goffman, E. (1963) The Presentation of Self in Everyday Life. Garden City, NY: Anchor Books. 
Hays, S. (1996) The Cultural Contradictions of Motherhood. New Haven: Yale University Press.

Hendrick, H. (1997) 'Constructions and Reconstructions of British Childhood: an interpretative survey, 1800 to the present,' in A. James \& A. Prout, (eds) Constructing and Reconstructing Childhood, pp. 35-59. London: Falmer. Hill Collins, P. (1990) Black Feminist Thought: Knowledge, Consciousness and the Politics of Empowerment. Boston: Unwin Hyman.

James, A., Jenks, C., and Prout, A. (1998) Theorizing Childhood. Cambridge: Polity.

Jenks, C. (1996) Childhood. London: Routledge. Lawler, S. (1999) 'Children need but mothers only want: the power of "needs talk" in the constitution of childhood', in J. Seymour \& P. Bagguley (Eds) Relating Intimacies: Power and Resistance, pp. 64-99, Basingstoke: Macmillan. Lawler, S. (2000) Mothering the Self: Mothers, Daughters, Subjects. London: Routledge.

McHugh, P. (1970) 'A common-sense conception of deviance,' in J.D. Douglas (ed), Deviance and Respectability: the Social Construction of Moral Meanings, pp. 61-88. New York: Basic Books.

Miller, T. (2005) Making Sense of Motherhood: A Narrative Approach.

Cambridge: Cambridge University Press.

Murcott A. (1993) 'Purity and Oollution: body management and the social place of infancy', in D. Morgan \& S. Scott (eds) Body Matters: Essays on the Sociology of the Body. London: Falmer.

Murphy, E.A. \& Dingwall, R. (2003) Qualitative Methods and Health Policy Research. New York: Aldine.

Pollock, L. (1983) Forgotten Children. Cambridge: Cambridge University Press,. Ribbens, J. (1994) Mothers and their Children: a Feminist Sociology of Childrearing. London: Sage. 
Ribbens McCarthy J., Edwards R. \& Gillies V. (2000) Parenting and Stepparenting: Contemporary Moral Tales. Occasional Paper 4, Centre for Family and Household Research, Oxford Brookes University.

Robertson, P. (1976) 'Home as a nest: niddle class childhood in nineteenthcentury Europe,' in L. de Mause (ed), The History of Childhood. London: Souvenir Press.

Rose, N. (1996) 'Identity, genealogy, history', in S. Hall \& P. du Gay (eds) Questions of Cultural Identity. London: Sage.

Schutz, A. (1954) 'Concept and theory formation in the social sciences', Journal of Philosophy, 51: 257-73.

Shorter, E. (1976) The Making of the Modern Family. London: Collins.

Stainton Rogers R. and Stainton Rogers W. (1992) Stories of Childhood: Shifting Agendas of Child Concern. Hemel Hempstead: Harvester/Wheatsheaf.

Stainton Rogers W. (2001) 'Constructing childhood: constructing child concern,' in P. Foley, J. Roche and S. Tucker (eds) Children in Society: Contemporary Theory, Policy and Practice. Basingstoke: Palgrave.

Steedman, C. (1990) Childhood, Culture and Class in Britain: Margaret McMillan 1860-1931. London: Virago.

Stone, L. (1977) The Family, Sex and Marriage in England 1500-1800. London: Weidenfield and Nicolson.

Urwin, C. (1985) 'Constructing motherhood: the persuasion of normal development', in C. Steedman, C. Unwin \& V. Walkerdine (eds) Language, Gender and Childhood, pp. 164-202. London: Routledge and Kegan Paul.

Woodhead M. (1997) 'Psychology and the cultural construction of children's needs', in A. James \& A. Prout (eds) Constructing and Reconstructing Childhood, second edition, pp. 63-76. London: Falmer Press 


\section{AUTHOR REFERENCES}

Murphy E. (2004) 'Anticipatory accounts', Symbolic Interaction, 27 (2): 129-154.

Murphy, E. (2004) 'Risk, maternal ideologies and infant feeding', in L. Williams and J. Germov (eds) The Social Appetite: an Introduction to the Sociology of Food and Nutrition, Second edn. Melbourne: Oxford University Press.

Murphy E. (2003) 'Expertise and forms of knowledge in the government of families', The Sociological Review 51 (4): 433-462.

Murphy E.A. (2000) 'Risk, Responsibility and Rhetoric in Infant Feeding', Journal of Contemporary Ethnography, 29 (3): 291-325.

Murphy E.A. (1999) '"Breast is Best": Infant feeding and maternal deviance', Sociology of Health and Illness, 21 (2):187-208. 
Table One: Characteristics of 36 study participants

\begin{tabular}{|l|c|c|c|c|}
\hline & $\begin{array}{l}\text { Occupational } \\
\text { Class 1/2 } \\
\text { (professional/ } \\
\text { intermediate) }\end{array}$ & $\begin{array}{l}\text { Occupational } \\
\text { Class 3 (skilled } \\
\text { non-manual/ } \\
\text { manual) }\end{array}$ & $\begin{array}{l}\text { Occupational } \\
\text { class 4/5 } \\
\text { (semi-skilled/ } \\
\text { unskilled }\end{array}$ & Total \\
\hline $\begin{array}{l}\text { Above mean } \\
\text { age at birth of } \\
\text { first baby }\end{array}$ & 6 & 6 & 6 & 18 \\
\hline $\begin{array}{l}\text { Below mean } \\
\text { age at birth of } \\
\text { first baby }\end{array}$ & 6 & 6 & 6 & 18 \\
\hline Total & 12 & 12 & 12 & 36 \\
\hline
\end{tabular}

Note: Classifications come from UK Registrar General's Classification of

Occupational Class (Office of Population Censuses and Surveys 1980). Class 1/2 examples include lawyers, teachers, nurses, managers. Class 3 examples include typists, shop assistants, technicians. Class $4 / 5$ examples include packers, cleaners and machine operatives. 
Acknowledgements

This study was funded by the UK Economic and Social Research Council, as part of the Nation's Diet Programme (L209252035). I am grateful to the women and health professionals who took part in the study and to Professor Tony Avery and Lindsay Groom of the Division of General Practice at the University of Nottingham who gave valuable assistance in locating and gaining access to the practices from which the sample was drawn. Manchester Information Datasets and Associated Serves at the University of Manchester helped us to access UK Census SAS/SBS data. Special thanks are also due to Susan Parker and Christine Phipps, who carried out the interviews and some of the preliminary analysis on which this article based and to Anne Murcott, Alison Edgley and two anonymous referees for helpful comments on earlier drafts of this article. 
Notes

${ }^{i}$ Data extracts are followed by an indication of the occupational class grouping (highest/intermediate/lowest) to which each woman belonged and whether she was in the older or younger subdivision of that grouping. The ethnicity of the informants is also indicated (WB=White British; $A C=$ African Caribbean; $S A=$ South Asian). See Table One for details of the age and occupational class of informants. 